\title{
Pengaruh Latihan Skipping Terhadap Kecepatan Tendangan Sabit Peserta Ekstrakurikuler di SMP Negeri 1 Nagrak Kabupaten Sukabumi
}

\section{The Influence of Skipping Exercise on the Speed of sickle kick of Extracurricular Participants in Junior High School of State 1 Nagrak District of Sukabumi}

\author{
Fian Ferdiansyah \\ Universitas Muhammadiyah, Kota Sukabumi, Jawa Barat Indonesia \\ Ferdiansyahfian171@gmail.com
}

\begin{abstract}
ABSTRAK
Tujuan dari penelitian ini adalah Untuk mengetahui pengaruh latihan skipping serta pengaruh latihan tradisional/konvensional terhadap kecepatan tendangan sabit peserta ekstrakurikuler pencak silat di SMP Negeri 1 Nagrak Kabupaten Sukabumi, maupun perbedaan pengaruh latihan skipping dengan latihan tradisional/konvensional terhadap kecepatan tendangan sabit peserta ekstrakurikuler pencak silat di SMP Negeri 1 Nagrak Kabupaten Sukabumi.

Teknik pengambilan sampel yang digunakan adalah teknik sampel jenuh dimana semua anggota populasi digunakan sebagai sampel dengan teknik pengumpulan data yang digunakan yaitu observasi langsung, dokumentasi, serta menggunakan alat untuk melakukan penelitian. Sedangkan teknik analisis data yang digunakan adalah mencari rata-rata hitung, uji normalitas menggunakan teknik Kolmogorov-Smirnov dan Shafiro-Wilk test, uji homogenitas, Uji hipotesis dilakukan dengan menggunakan one sample test t-test.semua pengujian analisis data menggunakan SPSS.

Hasil dari penelitian adalah sebagai berikut 1) Ada pengaruh antara latihan dengan media skipping terhadap kecepatan tendangan sabit pada peserta ekstrakurikuler pencak silat SMP Negeri 1 Nagrak Kabupaten Sukabumi. 2) Tidak ada pengaruh antara latihan non program terhadap kecepatan tendangan sabit pada peserta ekstrakurikuler pencak silat SMP Negeri 1 Nagrak Kabupaten Sukabumi.3) Latihan dengan media skipping lebih berpengaruh terhadap kecepatan tendangan sabit pada peserta ekstrakurikuler pencak silat SMP Negeri 1 Nagrak Kabupaten Sukabumi.
\end{abstract}

Kata Kunci : Pengaruh, Latihan skipping, dan Tendangan Sabit

\section{ABSTRACT}

The purpose of this study was to determine the effect of skipping training and the effect of traditional / conventional training on the sickle kick speed of pencak silat extracurricular participants in SMP Negeri 1 Nagrak, Sukabumi Regency, as well as the difference between the effect of skipping training and traditional / conventional training on the speed of sickel kick pencak silat extracurricular participants in SMP Negeri 1 Nagrak, Sukabumi.

The sampling technique used is the saturation sample technique where all members of the population are used as samples with data collection techniques used, namely direct observation, documentation, and using tools to conduct research. While the data analysis technique used is to find the average count, the normality test uses the Kolmogorov-Smirnov and Shafiro-Wilk test, the homogeneity test, the hypothesis test is performed using one sample t-test. All data analysis tests use SPSS.

The results of the study are as follows 1) There is an effect between training with skipping media on the speed of the kick sickle on the pencak silat extracurricular participants 
at SMP Negeri 1 Nagrak, Sukabumi Regency. 2) There is no effect between non-program training on sickle kick speed on pencak silat extracurricular participants at SMP Negeri 1 Nagrak, Sukabumi Regency. 3) Training with skipping media has more influence on the speed of sickle kicks on pencak silat extracurricular participants at SMP Negeri 1 Nagrak, Sukabumi Regency.

\section{Keywords: Influence, Skipping Exercise, and Sickle kick}

\section{PENDAHULUAN}

Ekstrakurikuler pencak silat merupakan kegiatan siswa yang sudah rutin dilakukan dan sudah diterapkan di sekolah yang dilakukan sebanyak dua kali dalam seminggu di sekolah SMP Negeri 1 Nagrak yang dimulai sejak 14 oktober 2011. Pada saat pelaksanaan pelatihan semua peserta ektrakurikuler pencak silat diberikan penjelasan mengenai gerakan dasar dan teknik-teknik dalam pencak silat. Karena teknik dasar merupakan bagian terpenting dalam pencak silat bisa di bilang sebagai pondasi yang kuat sebelum mempelajarinya.

Teknik serangan pada pencak silat hanya menggunankan dua serangan yaitu tangan dan kaki. Serangan menggunakan kaki terdiri dari: tendangan lurus, tendangan sabit, tendangan " $T$ ", tendangan gejag, tendangan belakang, dan tendangan gajul. Tendangan merupakan salah satu teknik yang sering dilakukan pada saat bertanding dalam pencak silat karena sangat berpengaruh besar dibanding serangan tangan. Teknik serangan kaki salah satunya yaitu tendangan sabit, tendangan sabit dapat diartikan sebagai salah satu bentuk serangan yang arah gerakannya melingkar dari luar dan biasa disebut dengan tendangan busur. Adapun cara melakukannya yaitu:

Tendangan sabit merupakan tendangan dengan cara mengayunkan kaki dari samping dengan tumpuan punggung kaki secara melingkar sasarannya samping badan. Keunggulan dan kelemahan tendangan sabit yaitu, mempermudah menendang kearah bagian samping badan dengan cepat sehingga tidak mudah untuk ditakis. Adapun kelemahannya yaitu: apabila gerakan menendang kurang bertenaga maka lawan akan mudah menangkis dan menahan serangan yang diberikan. Penggunaan metode latihan yang kurang dalam latihan membuat para atlet kurang pada kualitas geraknya.

Menanggapi masalah diatas maka dari itu peneliti ingin memberikan sebuah model latihan yang dapat memberikan dampak positif bagi kualitas para anggota ekstrakurikuler khususnya pada kecepatan gerak, salah satunya ya 
dengan metode latihan dengan teknik skipping yang bertuuan untuk meningkatkan kualitas kecepatan tendangan sabit bagi para anggota ekstrakurikuler.

Dari pengamatan peneliti ternyata banyak peserta ekstrakurikuler 16 orang yang masih kurang optimal dalam melakukan tendangan sabit hal ini terlihat dari kecepatan tendangan sabit yang masih kurang baik sehingga masih bisa diantisipasi oleh lawan. Maka dari itu peneliti menerapkan latihan skipping, skipping adalah latihan kardio sederhana yang berdampak besar bagi tubuh yang bisa melatih power otot tungkai. Menurut Bayu Surya (2010:3) lompat tali dikenal dengan isitilah rope skipping. Lompat tali atau skipping adalah suatu aktivitas yang menggunakan tali dengan kedua ujung tali di pegang dengan kedua tangan lalu diayunkan melewati kepala sampai kaki melompat.

Berdasarkan uraian diatas, peneliti akan menggunakan teknik tendangan sabit dengan menerapkan metode latihan skipping sebagai kombinasi gerak dalam mengajarkan materi dalam kegiatan pembelajaran pencak silat pada siswa yang mengikuti ekstrakulikuler di SMP Negeri 1 Nagrak. Penulis meyakini dengan menerapakan metode latihan skipping yang dilakukan pada saat sebelum melakukan tendangan sabit bertujuan agar dapat meningkatkan kualitas kecepatan tendangan sabit pada Pencak silat, maka penulis tertarik untuk melakukan penelitian dengan judul "Pengaruh Latihan Skipping Terhadap Kecepatan Tendangan Sabit Peserta Ekstrakurikuler Pencak Silat di SMP Negeri 1 Nagrak Kabupaten Sukabumi”.

\section{METODE PENELITIAN}

Metode penelitian yang digunakan saat ini adalah metode penelitian eksperimen. Eksperimen adalah suatu cara untuk mencari hubungan sebab akibat antara dua faktor yang sengaja di timbulkan oleh peneliti dengan mengurangi faktor-faktor lain yang mengganggu. (Arikunto, 2006:3), menurut Sugiyono (2017: 72) sebagaimana dikemukakan bahwa:

penelitian eksperimen termasuk penelitian yang didasarkan pada tingkatkealamiahannya (natural setting) tempat penelitian selain penelitian survey dan naturalistic. Pada hakekatnya penelitian eksperimen (experimental research) adalah meneliti pengaruh perlakuan terhadap perilaku yang timbul sebagai akibat perlakuan.

Sedangkan menurut Mohamad Nazir (2014: 51) bahwa: “metode eksperimen adalah observasi dibawah kondisi buatan (artificial condition) dimana kondisi tersebut dibuat dan diatur oeh peneliti”.Dalam metode eksperimen ini menurut Nasir (2009:233) jenis eksperimen ada dua macam, yaitu eksperimen semu dan eksperimen murni. Eksperimen semu adalah rancangan percobaan yang belum secukupnya mempunyai sifat-sifat suatu percobaan sebenarnya. Sedangkan eksperimen murni adalah rancangan dimana aturan untuk 


\section{Jurnal Movement and Education}

Volume 1 nomor 1

menempatkan perlakuan pada unit percobaan dibuat sedemikian rupa, sehingga memungkinkan membuat perbandingan antar kelompok dengan validitas tinggi dan dapat mengontrol sumber-sumber variasi pada percobaan tersebut.

\section{Teknik Analisis Data}

1. Mencari rata-rata hitung (mean) variabel penelitian dan standar deviasi menggunakan analisis deskriptif data menggunakan bantuan software SPSS 21 for windows.

2. Uji Normalitas

Uji normalitas digunakan untuk menguji apakah data kontinyu berdistribusi normal sehingga analisis dengan validitas, reliabilitas, uji t, korelasi, regresi dapat dilaksanakan. Uji normalitas menggunakan teknik Kolmogorov-Smirnov dan Shafiro-Wilk test. Apabila uji normalitas menghasilkan nilai $\mathrm{p}>0.05$ pada taraf signifikansi 5\%, maka berdistribusi normal. Sebaliknya jika nilai $\mathrm{p}<0.05$ pada taraf signifikansi 5\%, maka berdistribusi tidak normal. Pada penelitian ini penghitungan menggunakan bantuan SPSS 21.

3. Uji Homogenitas

Uji Homogenitas Varians ini bertujuan untuk mengetahui apakah sampel berasal dari populasi yang homogen atau tidak dan memiliki signifikansi satu sama lain. Kriterianya apabila Fhitung < Ftabel maka varians sampel tidak homogen, rumus yang digunakan untuk menguji homogenitas bersumber dari Budi Susetyo (2017:160) adalah sebagai berikut:

$F=\frac{S_{\text {besar }}}{S_{\text {kecil }}}$

Keterangan rumus:

$\mathrm{S}=$ varian

Pengujian Homogenitas pada penelitian ini peneliti menggunakan bantuan SPSS 21.

4. Pengujian Hipotesis

Uji hipotesis dilakukan dengan menggunakan one sample test $t$-test. Pengujian menggunakan program software SPSS version 21 for windows dengan taraf signifikansi $5 \%$ atau 0.05 . pengujian uji t yaitu untuk menguji bagaimana pengaruh masing-masing variabel bebasnya secara sendiri-sendiri terhadap variabel terikatnya. Uji ini dapat dilakukan dengan membandingkan $t$ hitung dengan $t$ table.

Hipotesis statistic

$\mathrm{H}_{0}: \mathrm{r} \neq 0 \mathrm{~S}$

$\mathrm{H}_{1}: \mathrm{r}=0 \mathrm{SS}$ 
Jurnal Movement and Education

Volume 1 nomor 1

Artinya:

a. $\mathrm{H}_{0}$ : Tidak terdapat pengaruh yang signifikan dengan latihan menggunakan skipping terhadap hasil tendangan sabit peserta ekstrakurikuler pencak silat SMP Negeri 1 Nagrak Kabupaten Sukabumi.

b. $\mathrm{H}_{1}$ : Terdapat pengaruh yang signifikan dengan latihan menggunakan skipping terhadap hasil tendangan sabit peserta ekstrakurikuler pencak silat SMP Negeri 1 Nagrak Kabupaten Sukabumi.

Sesuai dengan penjelasan diatas maka secara garis besarnya alur penelitian ini dapat penulis gambarkan sebagai berikut:

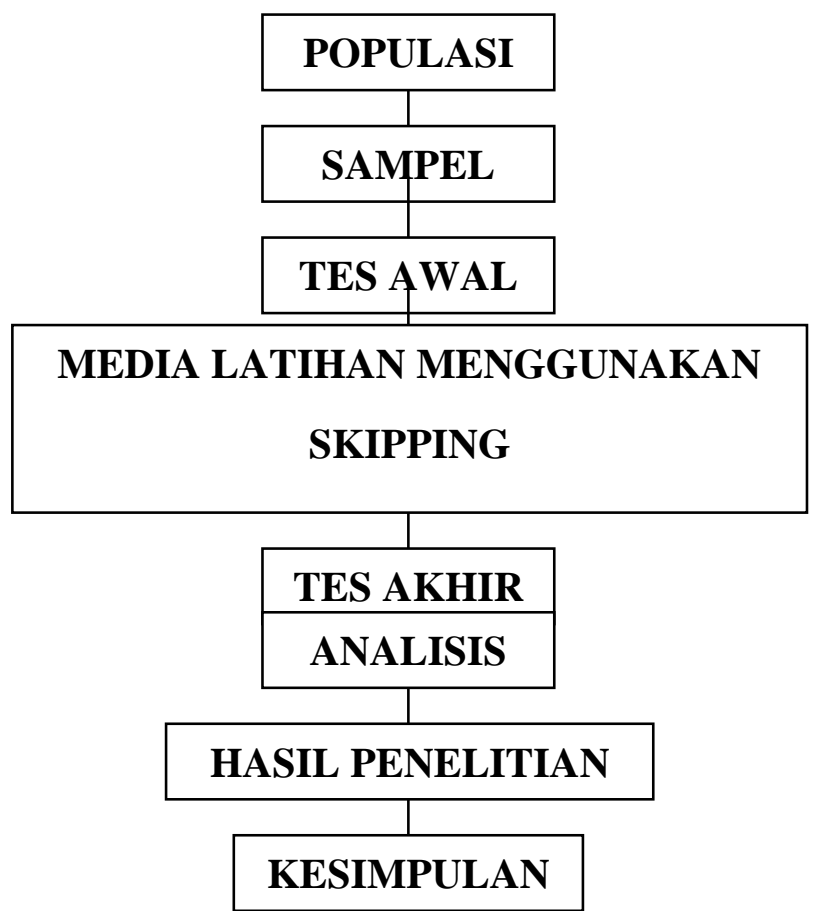

Gambar 3.1 Alur Penelitian

(Penulis, 2019) 


\section{HASIL DAN PEMBAHASAN}

Metode penelitian yang digunakan saat ini adalah metode penelitian eksperimen. Eksperimen adalah suatu cara untuk mencari hubungan sebab akibat antara dua faktor yang sengaja di timbulkan oleh peneliti dengan mengurangi faktor-faktor lain yang mengganggu. (Arikunto, 2006:3), menurut Sugiyono (2017: 72) sebagaimana dikemukakan bahwa:

penelitian eksperimen termasuk penelitian yang didasarkan pada tingkatkealamiahannya (natural setting) tempat penelitian selain penelitian surveydan naturalistic. Pada hakekatnya penelitian eksperimen (experimental research) adalah meneliti pengaruh perlakuan terhadap perilaku yang timbulsebagai akibat perlakuan.

Sedangkan menurut Mohamad Nazir (2014: 51) bahwa: "metode eksperimen adalah observasi dibawah kondisi buatan (artificial condition) dimana kondisi tersebut dibuat dan diatur oeh peneliti”.

Dalam metode eksperimen ini menurut Nasir (2009:233) jenis eksperimen ada dua macam, yaitu eksperimen semu dan eksperimen murni. Eksperimen semu adalah rancangan percobaan yang belum secukupnya mempunyai sifat-sifat suatu percobaan sebenarnya. Sedangkan eksperimen murni adalah rancangan dimana aturan untuk menempatkan perlakuan pada unit percobaan dibuat sedemikian rupa, sehingga memungkinkan membuat perbandingan antar kelompok dengan validitas tinggi dan dapat mengontrol sumber-sumber variasi pada percobaan tersebut.

\section{KESIMPULAN}

Kesimpulan pada penelitian ini selaras dengan pokok pertanyaan dalam penelitian yang tedapat dalam bab 1 yaitu terdapat hubungtan yang signifikan dengan melakukan latihan skipping terhadap kecepatan tendangan sabit pada peserta ekstrakurikuler pencak silat di SMPNEGERI 1 NAGERAK KABUPATEN SUKABUMI. hal itu berdampak positif bagi perkembangan peserta ekstrakurikuler untuk membantu dalam melakukan tendangan sabit 


\section{DAFTAR PUSTAKA}

Arman. (2018). Pengaruh Latihan Karet Ban Dalam dan Pemberat Kaki

Terhadap Kecepatan Tendangan Sabit Pesilat Putri Ekstrakurikuler

Pencak Silat SMP Negeri 2 Gunung Guruh Kabupaten Sukabumi. Skripsi

pada FKIP UMMI Sukabumi : tidak diterbitkan

Arikunto. (2010). Prosedur Penelitian: Suatu Pendekatan Praktek. Jakarta:

Rineka Cipta

Faqur, Muhammad Muhyi. (2009). Pendidikan Jasmani Olahraga dan Kesehatan Untuk SMP Kelas IX. Jakarta: CV. Setiaji.

Hadziq, K. (2013). Pendidikan Jasmani Olahraga dan Kesehatan untuk SMP MTs. Bandung: Yarma Widya.

Hariyadi, R. Kotot Slamet. (2003). Teknik Dasar Pencak Silat Tanding. Jakarta: PT.Dian Rakyat.

Harsono. (1988). Coaching dan Aspek-aspek Psikologis Dalam Coaching. Jakarta: CV. Tambak Kusuma.

Imanudin, Satriya. dan Dikdik. (2014). Teori Latihan Olahraga. Bandung: CV Nurani.

Kiswanto, E. Setyo. (2015). Pencak Silat. Yogyakarta: PT. Pustaka Baru Press.

Lubis, Johansyah. dan Wardoyo, Hendro. (2014). Pencak Silat. Jakarta: PT RajaGrafindo Persada.

Maryono, O. (2014). Pencak Silat Magazine: Menggempur Vietnam Syndrom. Jakarta: PB IPSI.

Muhajir. (2007). Penjasorkes SMA Jilid 2. Bandung: Erlangga

Mulyana. (2013). Pendidikan Pencak Silat. Bandung: PT Remaja Rosdakarya.

Nasir, M. (2009). Metodelogi Penelitian. Bogor: Ghalia Indonesia.

Nazir. (2014). Metodelogi Penelitian. Bogor: Ghalia Indonesia

Satriya, S. Dikdik Z. dan Imanudin, Iman. (2014). Bahan Ajar Teori Latihan Olahraga. Bandung: PKO FPOK UPI.

Sidik, Dikdik Zafar. Pesurnay, Paulus L. dan Afari,Luky. (2014). Pelatihan 
Jurnal Movement and Education

Volume 1 nomor 1

Kondisi Fisik. Bandung: PT Remaja Rosdakarya.

Sugiyono. (2007). Metode Penelitian kuantitatif kualitatifdan $R \& D$. Jakarta:

Alfabeta.

Sugiyono. (2017). Metode Penelitian Pendidikan. Bandung: Alfabeta.

Sukadiyanto. (2011). Pengantar Teori dan Metologi Melatih Fisik. Bandung: CV.

Lubuk Agung.

Surya, Bayu. (2010). ARENA Pendidikan Jasmani Olahraga dan Kesehatan.

Jakarta: PT. Sinergi Pustaka Indonesia.

Yudiana, Yunyun. Subardjah, Herman. dan Juliantine, Tite. (2007). Teori Latihan.

Bandung: UPI Press 